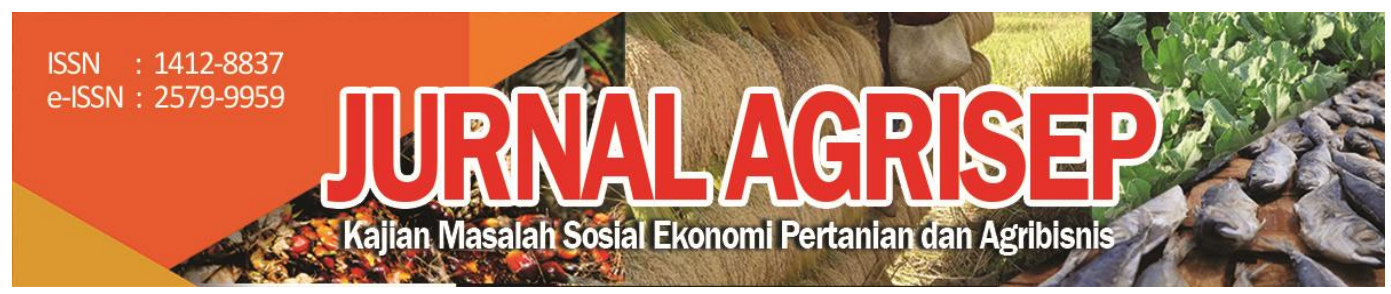

DOI: 10.31186/jagrisep.20.2.343-354

\title{
ANALISIS KELAYAKAN USAHATANI SELADA HIDROPONIK DI MASA PANDEMI COVID-19 KABUPATEN KOLAKA
}

\section{The Feasibility Analysis Of Hydroponic Lettude Farming During The Covid-19 Pandemic In Kolaka Regency}

\author{
Masitah $^{1)} \square$; Syahrir'2); Muhtar Amin ${ }^{3) ;}$ Poresman Mandeva ${ }^{4)}$ \\ 1,2,3,4)Program Studi Agribisnis, Fakultas Pertanian, Perikanan dan Peternakan \\ Universitas Sembilanbelas November Kolaka, Sulawesi Tenggara, Indonesia \\ Email: masitah.malla@gmail.com
}

\begin{abstract}
Hydroponic lettuce is one type of plant that is widely developed today by farmers to be used as a farm for the community, especially for millennials. Hydroponics is a way of farming that is again up to date in the midst of the current Covid-19 pandemic because it is not difficult to cultivate and can provide benefits for farmers. The purpose of the research was to determine the feasibility of hydroponic lettuce farming during the Covid-19 pandemic. The research was conducted in Kolaka Regency with a population of 19 hydroponic lettuce farmers. Business analysis that will be used in this study is income analysis $(\pi)$, Business Ratio $(R / C)$, Payback Period (PBP) and Break Even Point (BEP). The research was conducted in Kolaka Regency with a population of 19 hydroponic lettuce farmers. The results of the analysis of the feasibility of hydroponic lettuce farming during the Covid-19 pandemic are known to be profitable because the value of $R / C>1$ of 3.43 this indicates that the farm is profitable with the average income of hydroponic lettuce farming businesses already above the Kolaka District UMK of Rp. $2,502,500$, from the results of the analysis PBP obtained a figure of 0.3 years to return the investment of mangrove crab business takes about 3.6 months and to reach the break-even point (BEP) obtained a minimum gross receipt of $R p .840,349.3$ this means that the hydroponic lettuce farming during the Covid-19 pandemic is worth trying.
\end{abstract}

Keywords: Hydroponic Lettuce, Business Feasibility, Covid-19 Pandemic 


\section{ABSTRAK}

Selada Hidroponik merupakan salah satu jenis tanaman yang banyak dikembangkan saat sekarang oleh para petani hingga dijadikan usahatani bagi kalangan masyarakat khususnya bagi generasi milenial. Hidroponik merupakan cara bercocok tanam yang lagi kekinian di tengah masa pandemi Covid-19 saat ini karena tidak sulit untuk dibudidayakan serta dapat memberikan keuntungan bagi petani. Tujuan penelitian adalah untuk mengetahui kelayakan usahatani selada hidroponik selama masa pandemi Covid-19. Penelitian dilaksanakan di Kabupaten Kolaka dengan jumlah populasi sebanyak 19 petani selada hidroponik. Analisis usahatani yang akan digunakan adalah analisis pendapatan ( $\pi)$, Rasio usaha (R/C), Payback Period (PBP) dan Break Even Point (BEP). Hasil analisis kelayakan usahatani selada hidroponik selama masa pandemi Covid-19 diketahui menguntungkan karena nilai $R / C>1$ yakni 3,43 hal ini menunjukkan bahwa usahatani tersebut menguntungkan dengan rata-rata pendapatan pelaku usahatani selada hidroponik sudah diatas UMK Kabupaten Kolaka sebesar Rp. 2.502.500, dari hasil analisis PBP diperoleh angka 0,3 tahun untuk mengembalikan investasi usaha kepiting bakau membutuhkan waktu sekitar 3,6 bulan dan untuk mencapai titik impas (BEP) memperoleh penerimaan kotor minimal sebesar Rp. 840.349,3 hal ini berarti usahatani selada secara hidroponik selama masa pandemi Covid-19 ini layak untuk diusahakan.

Kata kunci : Selada Hidroponik, Kelayakan Usaha, Pandemi Covid-19

\section{PENDAHULUAN}

Selada (Lactuca sativa L.) merupakan salah satu dari jenis tanaman sayuran hortikultura yang saat ini dikenal banyak di kalangan masyarakat. Selain itu tanaman selada banyak dijadikan sebagai pelengkap makanan yakni lalapan serta bahan tambahan dari makanan siap saji. Selada merupakan jenis tanaman yang tidak terlalu membutuhkan perawatan dan sangat mudah untuk ditanam namun cepat memberikan hasil. Saat ini, selada banyak dibudidayakan secara hidroponik. Hidroponik merupakan teknologi budidaya tanaman yang mana dalam larutan nutrisinya dengan menggunakan media buatan misalnya pasir, kerikil, dan rockwool sebagai penunjang mekanik. Fungsi dari hidroponik adalah mengatasi keterbatasan lahan atau luas tanah yang dapat digunakan dalam proses budidaya serta meminimalisasi dampak dari keterbatasan iklim (Wibowo dan Asriyanti, 2013).

Selada merupakan salah satu komoditi hortikultura yang belum terdaftar pada produksi komoditi sayuran nasional. Selada tidak termasuk dalam komoditas utama baik skala prioritas maupun komoditi utama sayuran, akan tetapi selada memiliki potensial untuk dikembangkan di Indonesia karena memiliki prospek ekonomi yang cukup cerah (Rukmana, 1994). Selada Hidroponik merupakan tanaman yang saat ini mulai banyak dikembangkan oleh masyarakat termasuk para petani sayur konvensional. 
Usahatani hidroponik bukan hal baru bagi masyarakat saat ini, khususnya bagi generasi milenial. Sejak tahun 1990, jenis tanaman selada mulai berkembang di Indonesia hingga sekarang. Permintaan salada dalam negeri mengalami peningkatan tiap tahunnya terutama permintaan dari pasar modern yakni supermarket. Akibat dari tingginya permintaan selada dalam negeri, Indonesia melakukan impor selada untuk memenuhi kebutuhan tanaman selada dalam negeri. Hal ini menjadi peluang bagi petani untuk membudidayakan tanaman selada secara hidroponik.

Kabupaten Kolaka merupakan salah satu daerah yang sumber penghasilannya berasal dari hasil pertanian. Tanaman selada merupakan jenis tanaman yang tergolong masih jarang dibudidayakan di Kabupaten Kolaka, namun potensi dan kondisi lahan sangat memungkinkan untuk dilakukan budidaya tanaman selada, karena tanaman selada memliki potensi untuk dikembangkan di Kabupaten Kolaka. Usahatani selada hidroponik sudah mulai dilakukan di Kabupaten Kolaka namun hanya pelaku usahatani yang memiliki pengalaman yang melakukan budidaa selada hidroponik tersebut.

Pandemi Covid-19 merupakan wabah virus yang asalnya dari China masuk ke Indonesia. Dampak dari pandemi covid-19 membuat beberapa pelaku usaha mengalami kerugian akibat dari kebijakan terkait Covid-19. Salah satu kebijakan yang diterapkan di Indonesia adalah PSBB di hampir semua wilayah di Indonesia termasuk Kabupaten Kolaka. Akibat dari kebijakan ini, beberapa pelaku usaha mengalami penurunan pendapatan bahkan ada mengalami kerugian. Untuk pelaku usaha hidroponik ditengah pandemi Covid-19 juga mengalami penurunan omset usaha dibanding sebelum adanya Covid-19. Akan tetapi banyak juga bermunculan beberapa pelaku usaha sayur hidroponik yang baru dimasa pandemi covid-19.

Investasi dengan modal awal yang tinggi digunakan untuk membangun instalasi hidroponik, sarana dan prasarana lainnya yang menjadikan pertimbangan harga jual sayur-sayur yang relatif tinggi dibandingkan dengan harga sayur-sayur yang tidak ditanam menggunakan sistem hidroponik dipasaran (Boer etc, 2019). Oleh karena itu diperlukan untuk mengkaji mengenai usahatani hidroponik mulai dari hulu hingga hilir yang akan menghasilkan pendapatan bagi usahatani hidroponik serta untuk melihat modal tersebut akan kembali dalam jangka waktu berapa lama.

Sesuai dengan masalah di atas, maka perlu untuk dilakukan kajian penelitian lebih mendalam terkait tentang kelayakan usahatani selada hidroponik dengan tujuan untuk melihat besarnya biaya-biaya yang dikeluarkan dan pendapatan dari usahatani selada hidroponik selama masa pandemi Covid-19. Analisis tersebut diharapkan mampu memberikan gambaran peluang bisnis usahatani selada hidroponik dan dapat menguntungkan bagi pelaku usaha selada hidroponik khusunya dimasa pandemi Covid-19 saat ini. 


\section{METODE PENELITIAN}

Objek penelitian yang diteliti adalah kelayakan finansial usahatani selada hidroponik dimasa pandemi Covid-19. Penelitian dilaksanakan di Kabupaten Kolaka, penentuan daerah penelitian didasarkan atas pertimbangan bahwa di Kabupaten Kolaka banyak masyarakat yang mengusahakan tanaman selada hidroponik. Populasi penelitian yakni semua petani yang sedang membudidayakan selada dengan tehnik hidroponik yakni sebanyak 19 petani yang berada di Kabupaten Kolaka. Adapun sebaran jumlah petani selada hidroponik di Kabupaten Kolaka terdapat pada tabel 1.

Tabel 1. Jumlah Petani Selada Hidroponik di Kabupaten Kolaka, 2021.

\begin{tabular}{llcc}
\hline No & Kecamatan & Jumlah Petani & Presentase (\%) \\
\hline 1 & Kolaka & 8 & 42,11 \\
2 & Pomalaa & 6 & 31,58 \\
3 & Wundulako & 4 & 21,05 \\
4 & Tanggetada & 1 & 5,26 \\
\hline & Jumlah & 19 & 100,00 \\
\hline
\end{tabular}

Sumber: Data Primer setelah diolah, 2021.

Penelitian menggunakan desain kuantitatif untuk menganalisis kelayakan usahatani selada hidroponik dengan maksud untuk melihat nilai suatu kegiatan tertentu yang dilakukan apakah layak atau tidak, serta untuk melihat suatu usaha apakah dapat memberi keuntungan bagi perusahaan, yang mana bertujuan untuk memaksimalkan keuntungannya (Umar 2003). Oleh karena itu untuk mengetahui kelayakan dari usahatani selada hidroponik selama masa pandemi Covid-19 di Kabupaten Kolaka digunakan analisis sederhana yakni pendapatan, rasio usaha, PBP dan BEP.

\section{Analisis Pendapatan}

Analisis pendapatan digunakan untuk mengetahui semua variabel input serta output yang digunakan suatu usaha serta berapa keuntungan yang akan didapatkan dari usahatani yang dilakukan Soekartawi (2006). Berikut rumus pendapatan usahatani selada hidroponik selama masa pandemi Covid-19:

$$
\pi=T R-T C
$$

Keterangan:

$\pi \quad=$ Keuntungan usahatani selada hidroponik

TR = Total reveneu usahatani selada hidroponik

TC $=$ Total cost usahatani selada hidroponik

\section{Analisis Reveneu Cost Ratio (R/C)}

Analisis rasio usaha merupakan analisis yang digunakan untuk menghitung atas usahatani yang dijalankan sudah layak atau tidak. Adapun

346 | Masitah,Syahrir, Muhtar Amin, Poresman Mandeva; Analisis Kelayakan.. 
rumus dari Rasio keuntungan R/C usahatani selada hidroponik dapat dilihat pada rumus dibawah ini:

$$
R / C=\frac{T R}{T C}
$$

Keterangan:

$T R=$ Total reveneu usahatani selada hidroponik

TC = Total cost usahatani selada hidroponik

Kriteria Usaha:

$\mathrm{R} / \mathrm{C}>1$, Usahatani selada hidroponik layak

$\mathrm{R} / \mathrm{C}=1$, Usahatani selada hidroponik impas

$\mathrm{R} / \mathrm{C}<1$, Usahatani selada hidroponik tidak layak

\section{Payback Period (PBP)}

Payback period menggambarkan dari suatu investasi usahatani selada hidroponik, berapa lama waktu yang diperlukan atau dibutuhkan untuk mengembalikan dana investasi tersebut secara penuh. Adapun rumus dari payback period dapat dilihat pada persamaan dibawah ini:

\section{Keterangan:}

$$
P B P=\frac{T B T+T B V}{N B+T B T} \times 1
$$

TBT = Total biaya tetap usahatani selada hidroponik

TBV = Total biaya variabel usahatani selada hidroponik

$\mathrm{NB}=$ penerimaan bersih usahatani selada hidroponik

1. Analisis Break Even Point (BEP)

Break Even Point adalah alat analisis yang dilakukan untuk melihat seberapa besar kapasitas produksi minimum dari usahatani yang dijalankan agar investasi tersebut tidak mengalami kerugian tetapi juga belum menghasilkan keuntungan. Adapun persamaan dari BEP dapat dilihat pada persamaan dibawah ini:

$$
B E P \text { Rupiah }=\frac{T B T}{\left(1-\left(\frac{T B V}{N B}\right)\right.}
$$

Keterangan:

TBT = Total biaya tetap usahatani selada hidroponik

TBV = Total biaya variabel usahatani selada hidroponik

NB = Penerimaan bersih usahatani selada hidroponik 


\section{HASIL DAN PEMBAHASAN}

Studi kelayakan bisnis adalah salah satu jenis analisis yang dapat dilakukan pada suatu usaha yang akan diteliti. Selain itu studi kelayakan juga merupakan penelitian terhadap rencana usaha yang akan dilakanakan yang bukan hanya melihat layaknya suatu usaha atau tidak, melainkan juga pada saat usaha sedang dioperasionalkan secara rutin dengan tujuan untuk mencapai keuntungan yang maksimal dalam suatu waktu(Ibrahim, 2003). Studi kelayakan terhadap suatu usaha yang akan maupun sedang dijalankan penting untuk dilakukan gunanya untuk melihat sejauh mana kegiatan usaha yang dilakukan dapat memberi keuntungan atau dalam hal ini layak untuk dijalan oleh suatu perusahaan baik untuk usaha skala mikro maupun makro. Menghitung pendapatan usahatani, rasio usahatani, payback period usahatani dan break even point usahatani merupakan beberapa alat analisis usaha yang dapat dilakukan dan paling sederhana untuk digunakan pada usaha yang akan maupun sedang dijalankan (Suharyon dan S Edi, 2021). Melalui perhitungan tersebut dapat diketahui kelayakan usahatani selada hidroponik dimasa pandemi covid-19 di Kabupaten Kolaka.

\section{Pendapatan Usahatani Selada Hidroponik Pada Masa Pandemi Covid-19}

Pendapatan usahatani selada hidroponik dihitung dengan menggunakan perhitungan keuntungan (net benefit). Pendapatan usahatani selada hidroponik yang akan dianalisis dibatasi dengan pendapatan dari hasil panen tanaman selada hidroponik di Kabupaten Kolaka. Hasil produksi usahatani selada hidroponik berkisar antar 425-495 pohon/bulan dengan harga rata-rata senilai Rp. 3.500/pohon. Penerimaan pelaku usahatani selada hidroponik rata-rata senilai Rp. 2.502.500/bulan, dengan dikurangi total biaya usahatani selada hidroponik yaitu rata-rata senilai Rp. 727.500/bulan, maka pendapatan bersih petani selada hidroponik rata-rata senilai Rp. 1.775.000/bulan adapun rata-rata rasio usahatani selada hidroponik sebesar 3,43, dengan asumsi tiap pelaku usaha menginvestasikan uangnya sebesar Rp. 1,00 maka akan mendapat penerimaan senilai Rp. 3.43 atau manfaat sebesar Rp 3.43. Adapun tabel pendapatan usahatani selada Hidroponik dapat terlihat di Tabel 2.

Tabel 2. Pendapatan Usahatani Selada Hidroponik di Masa Pandemi Covid 19 di Kabupaten Kolaka Perbulan

\begin{tabular}{cccccccc}
\hline No & Uraian & $\begin{array}{c}\text { Hasil } \\
(\text { Pohon })\end{array}$ & $\begin{array}{c}\text { Harga } \\
(\mathrm{Rp})\end{array}$ & $\begin{array}{c}\text { Penerimaan } \\
(\mathrm{Rp})\end{array}$ & $\begin{array}{c}\text { Biaya } \\
(\mathrm{Rp})\end{array}$ & $\begin{array}{c}\text { Pendapatan } \\
(\mathrm{Rp})\end{array}$ & $\mathrm{R} / \mathrm{C}$ \\
\hline 1. & Rata-rata & 715 & 3.500 & 2.502 .500 & 727.500 & 1.775 .000 & 3,43 \\
2. & Minimal & 425 & 3.500 & 1.487 .500 & 525.500 & 962.000 & 2,83 \\
3. & Maksimal & 945 & 3.500 & 3.307 .500 & 987.500 & 2.232 .000 & 3,35 \\
\hline
\end{tabular}

Sumber: Data Primer setelah diolah, 2021.

348 | Masitah,Syahrir, Muhtar Amin, Poresman Mandeva; Analisis Kelayakan.. 
Tabel 2. terlihat bahwa penerimaan tertinggi usahatani selada hidroponik selama masa pandemic Covid-19 di Kabupaten Kolaka senilai Rp. 3.307.500/bulan, biaya operasional usahatani senilai Rp. 987.500/bulan sehingga menghasilkan pendapatan senilai Rp. 2.232 .000 dan rasio usahatani 3,25 . Sedangkan penerimaan usahatani terendah adalah senilai $R p$. 1.487.500/bulan dengan total biaya operasional usahatani senilai Rp. $525.500 /$ bulan sehingga total pendapatan bersih yang diterima pelaku usaha senilai Rp. 962.000/bulan dengan rasio usaha 2,83. Rasio usahatani selada hidroponik pada masa pandemi Covid-19 semuanya memiliki rasio usaha R/C $>1$ baik yang berpendapatan maksimum maupun yang minimum. Hal ini menunjukkan bahwa usahatani selada hidroponik dimasa pandemi Covid-19 masih layak atau masih menguntungkan untuk dijalankan. Hal ini sesuai dengan penelitian yang telah dilakukan oleh Novitasari et al. (2020) bahwa suatu usahatani selada layak untuk dijalankan atau dilanjutkan jika hasil analisis $\mathrm{R} / \mathrm{C}$ lebih dari 1 . Hal ini diperkuat dengan penelitian yang telah dilakukan Nana et al (2018) bahwa kegiatan usahatani selada air menguntungkan secara ekonomi ketika hasil rasio yang diperoleh lebih dari 1, maka dikatakan layak untuk dijalankan.

Perbedaan pendapatan usahatani selada hidroponik disebabkan oleh perbedaan hasil panen dari masing-masing pelaku usaha, sedangkan perbedaan hasil panen disebabkan oleh beberapa faktor diantaranya perbedaan usaha panen tanaman selada hidroponik atau perbedaan jumlah panen tanaman selada hidroponik perbulan, dimana jumlah panen tertinggi perbulan sebanyak 30 kali panen dengan hasil sebesar 945 pohon per bulan. Sedangkan yang terendah hanya mampu memanen sebanyak 15 kali panen dalam sebulan dengan hasil sebesar 425 pohon/bulan, semakin tinggi upaya panen maka hasil panen akan semakin maksimal. Selain itu perbedaan pendapatan usahatani selada juga dipengaruhi oleh perbedaan jumlah lubang tanam yang dioperasionalkan oleh tiap petani, semakin banyak jumlah lubang tanam yang dioperasionalkan maka hasil panen juga semakin besar. Hal ini sejalan dengan penyataan Paridy et al (2020) bahwa jumlah hasil produksi atau panen suatu usahatani mempengaruhi jumlah pendapatan yang dihasilkan oleh petani selain itu teknik pemasaran yang baik merupakan salah satu cara meningkatkan pendapatan usahatani. 


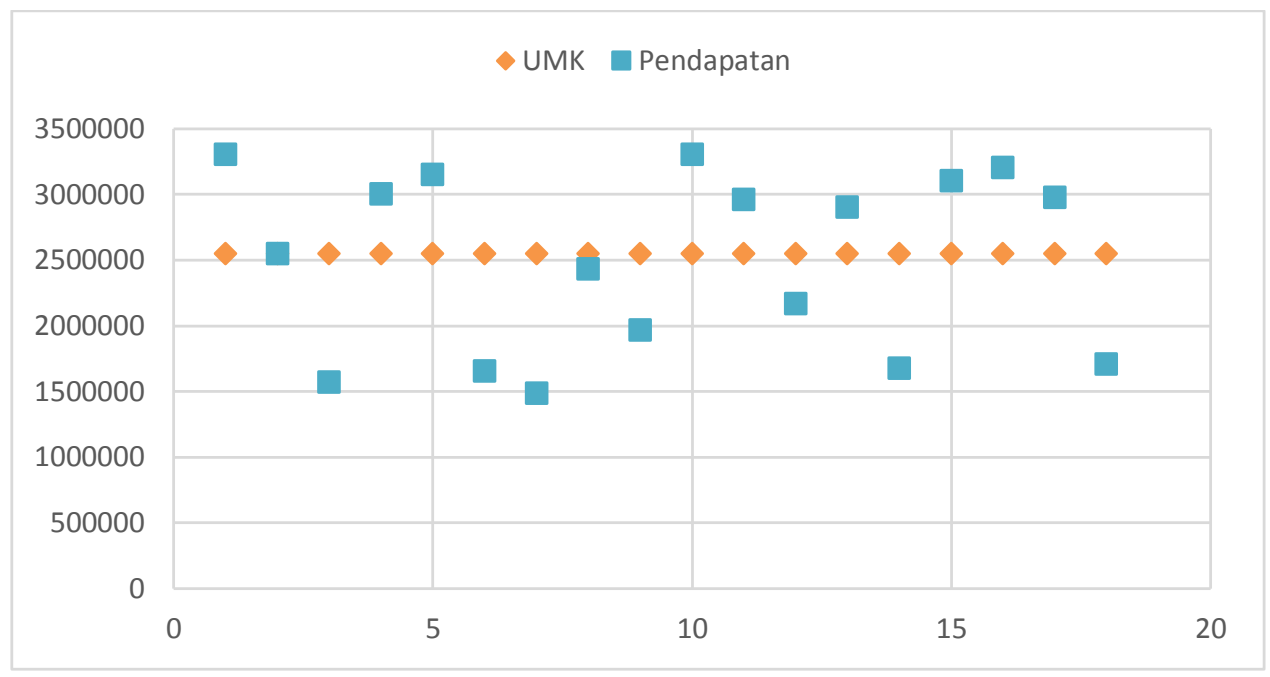

Gambar 2.

Tingkat Pendapan Bersih Usahatani Selada Hidroponik Selama Pandemi Covid-19 dibanding dengan UMK Kabupaten Kolaka 2021 (Sumber: Data Primer setelah diolah)

Tingkat pendapatan usahatani selada di Kabupaten Kolaka dari 19 responden jika dibandingkan dengan upah minimum kerja (UMK) Kabupaten Kolaka tahun 2021 sebesar Rp. 2.552.014/bulan terdapat tiga kelompok. Kelompok pertama adalah pelaku usahatani yang berpendapatan diatas UMK sebanyak 9 responden. Kelompok kedua adalah pelaku usahatani yang berpendapatan hampir sama dengan nilai UMK sebanyak 2 responden dan kelompok ketiga adalah pelaku usahatani yang berpendapatan di bawah nilai UMK dengan jumlah sebanyak 7 responden (Gambar 2). Berarti sebagian besar status masyarakat pelaku usahatani selada hidroponik di Kabupaten Kolaka kehidupannya sudah layak diatas dari garis kemisikinan terlebih dimasa pandemi Covid-19 saat ini. Hal ini sesuai sejalan dengan pendapat dari Rayyani et al (2020) bahwa saat wabah pandemi Covid-19 melanda Indonesia mulai Februari 2020, beberapa jenis usaha salah satunya adalah usaha mikro yang mana merupakan salah satu usaha yang paling rentan mengalami kerugian bahkan gulung tikar akibat dari adanya kebijakan terkait Covid-19 diantaranya kebijakan PSBB. PSBB merupakan satu dari beberapa kebijakan yang diberlakukan oleh pemerintah guna meminimalisir penyebaran Covid-19, meskipun langkah tersebut mengakibatkan pelaku usaha mengalami kerugian. Usaha yang dilakukan para pelaku usaha yakni dengan melakukan sistem penjualan online dengan cara memanfaatkan media sosial untuk meningkatkan penjualan yang menurun akibat pandemic Covid-19. 
Tabel 3. Analisis Kelayakan Usahatani Selada Hidroponik Selama Masa Pandemi covid-19 di Kabupaten Kolaka

Cash Flow Usahatani Selada Hidroponik Kabupaten Kolaka
A. Biaya Tetap
$425.350,00$
B. Biaya Variabel (1 Tahun)
$8.730 .000,00$
C. Penyusutan Modal 20\% x
$85.070,00$
D. Total Biaya Variabel $(B+C)$
$8.815 .070,00$
E. Penerimaan
$30.030 .000,00$
F. Net Benefit (E - D)
21.214.930,00
Analisis Usaha
1. Cash Flow $(\mathrm{F}+\mathrm{A})$
21.640.280,00
2. $\mathrm{PBP}[(\mathrm{A}+\mathrm{D}):(\mathrm{F}+\mathrm{A}) \times 1 \mathrm{th}]$
0,30
3,64
3. BEP Unit (kg):X
Harga Rata-rata $(\mathrm{P})$
$3.500,00$
Biaya Variabel Unit $(\mathrm{V})$
$1.728,4451,00$
BEP Unit $(X)=A(P-V)$
$240,0998,00$
Nilai BEP $=(\mathrm{PxX})$
$840.349,30$
R/C Ratio
2,02

Tahun

Bulan

Sumber: Data Primer setelah diolah. 2021.

\section{Payback Period (PBP)}

Analsis Payback Period (PBP) usahatani selada hidroponik di Kabupaten Kolaka bertujuan untuk melihat berapa periode atau waktu yang dibutuhkan untuk dapat mengembalikan investasi usaha yang telah dikeluarkan pelaku usahatani selada hidroponik dengan menggunakan net cash flows (aliran kas netto). Dengan kata lain untuk melihat sejauh mana jangka waktu yang dibutuhkan bagi pelaku usaha untuk mengembalikan secara penuh investasi yang telah dikeluarkan pelaku usaha dengan cara menghitung keuntungan yang didapatkan dari usahatani selada hidroponik. Dari hasil analisis PBP diperoleh angka 0,3 tahun, artinya untuk mengembalikan investasi usahatani selada hidroponik tersebut membutuhkan waktu sekitar 0,3 tahun atau 3,6 bulan. Sesuai dengan pernyataan Ramadhanty et al (2020) bahwa perhitungan investasi payback period dilakukan dengan tujuan untuk melihat berapa lama waktu atau periode pengembalian modal suatu usaha. Selain itu penelitian Manalu dan Lavyana (2020) juga mengatakan bahwa modal investasi dapat kembali dalam jangka waktu tertentu dan layak untuk dilanjutkan dikarenakan lebih kecil dari umur bisnis yakni 10 tahun. Oleh karena itu, berdasarkan kriteria tersebut usahatani selada hidroponik pada masa pandemic Covid-19 di 
Kabupaten Kolaka layak untuk dijadikan usaha atau layak untuk dikembangkan.

\section{Break Even Point (BEP)}

BEP merupakan jumlah antara pendapatan dan jumlah total biaya seimbang atau sama sehingga tidak terjadi kerugian atau tidak juga mendapatkan keuntungan dalam suatu usaha tersebut atau dalam hal ini impas. BEP usahatani selada dimasa Covid-19 di Kabupaten Kolaka digunakan untuk menganalisis proyeksi hasil panen yang harus dihasilkan dari usahatani selada hidroponik sehingga menghasilkan titik impas atau dengan kata lain kembali modal. Dari hasil analisis, didapatkan angka panen minimal yang harus dihasilkan oleh petani selada hidroponik untuk mencapai titik impas $(B E P)$ guna memperoleh penerimaan kotor minimal sebesar Rp. 840.349,30 dengan BEP harga yang dibebankan pada setiap produk. Hal ini sesuai dengan penelitian dari Chasana (2018) dengan hasil penelitian yang menyatakan bahwa hasil BEP diperoleh yakni sebesar 0,35 yang mana merupakan titik impas dari usaha yang dijalankan. Selain itu pernyataan tersebut sejalan dengan penelitian yang juga dilakukan oleh Kamaruddin et al (2020) bahwa usaha sayuran hidroponik sistem NFT skala kecil menguntungkan dengan melihat dari jumlah produksi yang melebihi BEP produksi, tingkat harga yang melebihi BEP harga, dan penerimaan yang melebihi BEP penerimaan.

\section{SIMPULAN DAN SARAN}

\section{Simpulan}

Hasil analisis kelayakan usahatani selada hidroponik selama masa pandemi Covid-19 diketahui menguntungkan karena nilai $R / C>1$ yakni 3,43 hal ini menunjukkan bahwa usahatani tersebut menguntungkan dengan ratarata pendapatan pelaku usahatani selada hidroponik sudah diatas UMK Kabupaten Kolaka sebesar Rp. 2.502.500, dari hasil analisis PBP diperoleh angka 0,3 tahun untuk mengembalikan investasi usaha kepiting bakau membutuhkan waktu sekitar 3,6 bulan dan untuk mencapai titik impas (BEP) memperoleh penerimaan kotor minimal sebesar Rp. 840.349,3. Ini berarti usahatani selada secara hidroponik dimasa pandemi Covid-19 layak diusahakan atau dijadikan usaha.

\section{Saran}

Saran yang direkomendasikan oleh peneliti adalah dalam meningkatkan jumlah hasil produksi selada hidroponik ditengah masa pandemi Covid-19 serta keberlanjutan usahatani, diperlukan keterampilan dalam memasarkan selada serta memaksimalkan penggunaan wadah tanaman hidroponik secara 
baik melalui pelatihan, pengetahuan pemahaman kepada petani mengenai budidaya tanaman hidroponik yang baik. Bagi pemerintah diharapkan dapat mampu memberikan kebijakan lain yang mampu menjaga kesejahteraan ekonomi pelaku usaha agar tetap terjamin pada waktu-waktu krusial seperti akibat dari adanya pandemi Covid-19 seperti saat sekarang ini. 


\section{DAFTAR PUSTAKA}

Boer, N, P., Abdi, dan Abdul, G. 2019. Analisis Kelayakan Finansial Usaha Hidroponik Di Kelurahan Kambu Kecamatan Kambu Kota Kendari (Studi Kasus Hidroponik Faperta). Jurnal Ilmiah Agribisnis. 6(1): 27-36

Chasana, U. 2018. Analisis Pendapatan Usahatani Sayuran Selada Merah Dengan Menggunakan Metode Hidroponik. Agrisains Jurnal Budidaya Tanaman Perkebunan Politeknik Hasnur. 4(2): 22-29

Ibrahim, Y. 2003. Studi Kelayakan Bisnis. Jakarta: Rineka Cipta

Kamaruddin, C, A., Ma'ruf, M, I., Marhawati, Basra, A., dan Rahmawati, D. 2020. Analisis Usaha Hidroponik Di Kota Makassar (Studi Kasus Delta Farm). Jurnal Agribisnis dan Sosial Ekonomi Pertanian UNPAD. 5(2): 151161

Manalu, D, S, T dan Bangun, L. 2020. Analisis Kelayakan Finansial Selada Keriting dengan Sistem Hidroponik (Studi Kasus PT Cifa Indonesia). Journal of Agriculture and Human Resource Development Studies. 1(2): 117126

Nana, F., Kune, S, J dan Hutapea, A, N. 2018. Analisis Pendapatan Usahatani Selada Air di Desa Popnam, Kecamatan Noemuti, Kabupaten Timor Tengah Utara. Jurnal Agrimor. 3(1): 13-15

Novitasari, D dan Syarifah, R, N, K. 2020. Analisis Kelayakan Finansial Budidaya Selada Dengan Hidroponik Sederhana Skala Rumah Tangga. Jurnal Sosial Ekonomi Pertanian dan Agribisnis. 17(1): 19 - 23

Paridy, R D., Masitah, M., dan Bahari, D . 2020. Marketing Channel Analysis in an Effort to Develop the Potential of Bananas in Pinrang Regency. Agribusiness Journal. 3(2): $1-7$

Ramadhanty, A, R., Wiyono, S, N., Kusno K., dan Trimo L. 2020. Analisis Kelayakan Usaha Budidaya Selada Krop Di Cv. Cantigi Desa Cikandang Kecamatan Cikajang Kabupaten Garut. Forum Agribisnis. 10(1) : $27-35$

Rayyani, W, O., Salam, K, N., Panjaitan, R., Nur, A., Sari, A, E., Nurussama, Wulansari, R., Krisnanto, B., Oktovian, R., Budiasih, Y. 2020. Masamasa Covid-19 Strategi Bisnis dan Manajemen Perusahaan. Komunitas Dosen Bidang Ekonomi dan Bisnis di Indonesia. Banten: CV. AA Rezky

Riyanto, B. 2004. Dasar-Dasar Pembelanjaan Perusahaan. Edisi ke 4.Yogyakarta: BPFC

Roidah, I. 2014. Pemanfaatan Lahan Dengan Menggunakan Sistem Hidroponik. Jurnal Universitas Tulungagung Bonorowo. 1(2): 43-49

Rukmana, R. 1994. Bertanam Selada \& Andewi. Yogyakarta: Kanisius

Soekartawi. 2006. Analisis Usahatani. Jakarta: UI Press

Suharyon dan Edi, S. 2021. Revenue and Feasibility Analysis of Celery (Apium Graveolens, L.) in Lingkar Selatan Village Paal Merah District Jambi City. IOP Conf. Series: Earth and Environmental Science. 715 (2021):1-7

354 | Masitah,Syahrir, Muhtar Amin, Poresman Mandeva; Analisis Kelayakan.. 
Susilawati, 2019. Dasar-Dasar Bertanam Secara Hidroponik. Palembang: Universitas Sriwijaya

Umar, H. 2003. Studi Kelayakan Bisnis. Edisi 2. Jakarta: Gramedia Pustaka Utama.

Umikalsum, R, A. 2019. Analisis Usahatani Tanaman Selada Hidroponik Pada Kebun Eve's Veggies Hydroponics Kota Palembang. Jurnal Societa. $7(1): 52-57$

Wibowo, S., dan Asriyanti, A, S. 2013. Aplikasi Hidroponik NFT Pada Budidaya Pakcoy. Jurnal Penelitian Terapan. 13(3): 159-167

Widiyanto, A. 2019. Analisis Kelayakan Finansial Usahatani Selada Dengan Sistem Hidroponik NFT. Jurnal Chlorophil. 12(1) : 1-9 